\title{
CHAPTER NINETEEN
}

\section{THE OPIUM REGIME OF THE DUTCH (COLONIAL) STATE, 1850-1940}

Multatuli's 'robber state' was also a state with a state bureaucracy. It was a colonial state directed at the exploitation of foreign territories without being asked to do so by the indigenous rulers and population, and whether legally or morally allowed, relevant or desirable. At the beginning of the 19th-century, this state and its bureaucracy were rather abstract entities; thunderclouds in a Western tempest with devastating lightning strikes. Of course, the elite had no knowledge of who lived there "far below"and under what conditions and, therefore, what effects this "natural disaster" had. And had forgotten how immense the area was in which this Western Tempest played havoc. For the new Dutch rulers, the island of Java was the only area they ruled for a long time; the enclosed map was not at their disposal.

Therefore, the actual opium distribution in Java had to be done by indigenous people who knew the ways to reach the consumers. The colonial state had to use opium farmers, but this changed at the end of the century as the Dutch became more accustomed to the East Indies and the East Indian people to them.

Then the Opiumregie was introduced, and its grip on the opium market became unparalleled compared to the VOC or the previous period. This time not only Java and Madura were the center of all activities, but the whole of the archipelago became occupied in a new series of devastating campaigns. Officially, however, the Opiumregie was aimed at minimizing or even eradicating opium consumption. There was no place for competition, not even of the NHM: the Opiumregie had a monopoly, not only in Java and Madura but also in the rest of the archipelago. Therefore, let us start with a few remarks about this "rest", and later the performance of the Opiumregie itself will be scrutinized.

\section{The Outer Districts}

As stated above, the better penetration of the Dutch opium business into the Outer Districts was already another feature of Dutch rule in the 19th- 


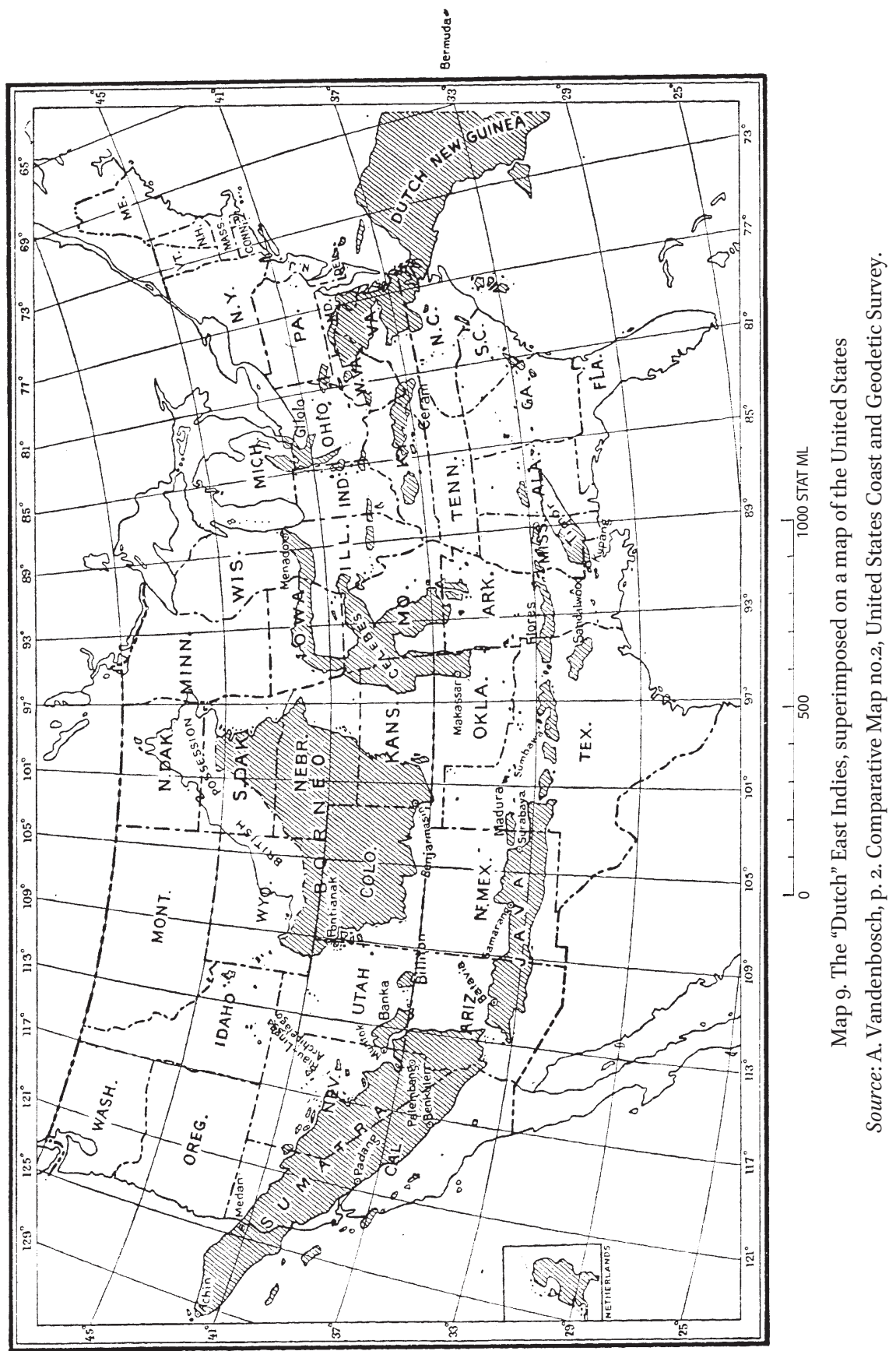


century and a parallel effect of the protracted conquest of parts of this archipelago; conquests which were followed up at the beginning of the 2oth-century a few years before the Dutch were kicked out of the realm. Neither the VOC nor the Amphioen Society cared much in this respect for other parts of the archipelago than Java and Madura. They certainly had their customers on specific islands like Bali, but there was no regular, let alone systematic, export from Batavia to elsewhere in the archipelago.

Many of these Outer Districts were situated on the route from Bengal along Sumatra, the Strait of Malacca (Melaka), Singapore, Borneo, etc. Along this route they were visited mostly by non-Dutch traders, who were immediately called "smugglers" by the Dutch. The English country traders and Chinese were the most important ones, but the Buginese traders were also rather active. This non-Dutch network was strengthened after Singapore became more important as the main port in the trade between India-East Indies-China.

Another important reason was that Dutch opium was always cost more than the opium from elsewhere. This situation did not change from the Napoleonic era, through the British occupation of Java or in the 2oth-century. On the contrary, British and American opium traders now had the best chance to attack their traditional Dutch competitor. Their only limit was Raffles' strong anti-opium and anti-slavery stand and the military protection the high-priced opium got from the Dutch. To avoid consumption, the British only levied an opium tax in the Outer Districts, but it is doubtful whether anybody cared to collect it.

Yet the rationalization of the opium distribution by means of government opium dens (Daendels, 1809) was continued after the restoration of the Dutch government. Opium dens were also spread over the Outer Districts, leading to a more systematic distribution of opium. ${ }^{1}$ In Ambon, Timor, Ban(g)ka-Belitung (Billiton) or Celebes, official opium dens were established. However, the license-holders often had to collect their opium not from the Java-based government but from the "smugglers"! At the end of the 19th-century, with the establishment of the Opiumregie, this big hole in the government opium network started to close. The closing of it required at least one real Opium War (see below). Until this new organization was functioning, the leasers of the opium dens had to pay for the license and taxes relative to the consumption.

\footnotetext{
1 J.C. Baud, p. 192 ff.
} 
The reasoning behind it must have been a pragmatic one for an exploiter: what was lost to the smugglers should be shifted towards their "own" consumers. It was a system which allowed many possibilities for corruption on all sides. As long as the government in Batavia could collect its half a million guilders annually from the districts, it was not concerned. The following table gives examples of how that half million was distributed over most districts in the middle of the 19th-century. One must realize that it was Baud, one of the highest officials in the colony, who estimated the so-called "smuggling".

Table 13. Net Output of Opium Leasing in Outer Districts of the East Indies, $1847-1849^{2}$

\begin{tabular}{lrrrr}
\hline DISTRICT & 1847 (Guilders) & 1848 (Guilders) & 1849 (Guilders) & $\begin{array}{c}\text { Estimated } \\
\text { smuggling } \\
\text { (chests) }\end{array}$ \\
\hline Moluccas & 25767 & 32421 & 32187 & 19 \\
Bali, Timor, etc. & 2150 & 3120 & 3300 & 10 \\
Macassar & 53037 & 81880 & 34240 & 40 \\
Banjarmasin & 12787 & 4480 & 15482 & 9 \\
Pontianak & 56900 & 71300 & 59466 & 115 \\
Riau & 63000 & 67500 & 55200 & 50 \\
Banca & 68482 & 60789 & 63010 & 21 \\
Padano +Aceh & 200022 & 189640 & 192490 & 160 \\
Bencoolen & 19125 & 20810 & 21120 & 80 \\
Palembang & 23460 & 25900 & 29760 & 12 \\
TOTAL & 509049 & 523407 & 531834 & 516 \\
\hline
\end{tabular}

This table reveals a few remarkable things. When this distribution occurs, the total opium income of the Dutch colonial state in these years was 6.7, 6.5 and 6 million guilders, respectively. ${ }^{3}$ This means that about six million guilders were provided every year by Java and Madura alone. These two islands are the most populous ones and the headquarters of the Dutch occupation and the NHM, but this is untenable. Also, the weights for Java and Madura (Baud: 390-375 chests per year in the period 1845-1849) in relation to the earnings are ridiculous. The first conclusion is, therefore,

2 Idem, p. 193. Padano (Padang) is situated at the middle West Coast of Sumatra above Bencoolen; Banjarmasin is a district in the south of Borneo; Riau is suggested as belonging to a group of islands south of Singapore. The sales in these districts are estimated for the years 1849-1850 by Baud, p. $180 \mathrm{ff}$.

3 Idem, p. 220. See also the article of R. Elson in A. Booth et. al (ed.), p. 41 column 2, who does not indicate which factor applies to "guilders": $\times 100$ or $\times 1000$. 
that the official Dutch statistics are quite dubious. This problem is in need of further investigation, but that cannot be done here. ${ }^{4}$

Looking for a further explanation, it could be assumed that the data are related to negotiations between the Dutch bureaucracy and the NHM: if the former got its money and the NHM its opium, then everybody must have been "satisfied"; data are only interesting for the motherland. The NHM as the main opium farmer "in Batavia" sells the opium to its own (unknown) customers somewhere in the whole realm. One must remember that the NHM trade operations reached even into China, the largest market for opium!

In this perspective, Baud's estimates of "smuggled" quantities in the archipelago receive a specific meaning, although they cannot be seen in relation to the other columns in the table. Baud's reflection on these smuggling data is:

... at the moment only among the leasers one can find the smugglers of substantial quantities ... in the VOC period there existed a right which every collaborator of the Company expected to have on the yield of socalled silent profits; at the moment the smuggler is confronted everywhere with the opinion that these profits are not only against the law, but are immoral as well ... if there should exist exceptions to this, one can find them only among the poorly remunerated personnel of low rank. It may be perceived as certain that the Chinese, who were major collaborators of the smugglers in the previous century, are still the same perpetrators ... ${ }^{5}$ (italics from Baud)

Therefore, we can also conclude that the NHM, with its extremely close relation to the Chinese traders and opium leasers, belongs among the main smugglers; we can at least expect that smuggling occurs with the silent approval of the NHM and that Baud, not a friend of the NHM, is suggesting this assumption.

4 More people do have difficulties with the statistics. Take the example of J. Meiss' doctoral dissertation from 1883 . J. Meiss, p. 65, reproduces the same table as given in the text without the smuggling estimates, while adding the totals of 1844-1846 (respectively 838,$071 ; 840,031$ and 825,089 ) and of $185^{0-51}$ (respectively 561,248 and 496,220). However, it is a pity that Meiss did not see a printing error in his table (in Bangka, 1847), but that all his totals from 1847-1849 are wrong is a remarkable mistake. The differences are between 250,000 and 300,000 guilders. My only explanation is that Meiss, for whatever strange reason, has taken only the totals from another source like Baud, namely the Koloniaal Verslag. In that case, it could be that the large differences between Meiss and Baud originate from a notation of tiban plus siram, while Baud's data could be based on the tiban only. But is this to be expected of Baud, the inventor of the tiban-siram system?

5 J. C. Baud, p. 182. 
Table 14. Opium consumption (in thails) of License and Non-License Holders in Java, Madura and Outer Districts (Buitengewesten) in the Opiumregie, $1930^{6}$

\begin{tabular}{|c|c|c|c|c|c|c|c|c|c|c|c|}
\hline \multirow[t]{3}{*}{ AREA } & \multicolumn{6}{|c|}{ HOLDERS OF A LICENSE } & \multicolumn{4}{|c|}{ NON-LICENSE HOLDERS } & \multirow{3}{*}{$\begin{array}{l}\text { Total } \\
\text { in } \\
\text { thails } \\
\mathrm{x} 100\end{array}$} \\
\hline & \multicolumn{2}{|c|}{ Europeans } & \multicolumn{2}{|c|}{ Chinese } & \multicolumn{2}{|c|}{ Indigenous } & \multicolumn{2}{|c|}{ Chinese } & \multicolumn{2}{|c|}{ Indigenous } & \\
\hline & no. & thails & no. & thails & no. & thails & no. & thails & no. & thails & \\
\hline West Java & 2 & 27 & 1943 & 36916 & 626 & 4258 & 5093 & 38731 & 3036 & 5570 & 855 \\
\hline Middle Java & 2 & 59 & 2702 & 50241 & 16184 & 61947 & 1874 & 14514 & 3193 & 5384 & 1321 \\
\hline East Java & 1 & --- & 3469 & 80108 & 33269 & 113677 & 1463 & 24106 & 1306 & 5226 & 2231 \\
\hline Djogjakarta & --- & --- & 456 & 9906 & 2132 & 9028 & -- & - & - & - & 189 \\
\hline Soerakarta & --- & --- & 935 & 14451 & 16630 & 52856 & --- & - & - & - & 673 \\
\hline $\begin{array}{l}\text { total Java }+ \\
\text { Madura }\end{array}$ & 5 & 86 & 9496 & 191622 & 68841 & 241767 & 8430 & 77351 & 7535 & 16180 & 5270 \\
\hline \multicolumn{12}{|c|}{ OUTER DISTRICTS (selection) } \\
\hline W.Sumatra & - & - & 280 & 5331 & 44 & 233 & - & - & - & - & 55 \\
\hline Palembang & - & - & 217 & 6176 & 7 & 35 & 1115 & 22343 & 20 & 199 & 288 \\
\hline E.Sumatra & - & - & 148 & 2857 & 117 & 924 & 36829 & 339542 & 3515 & 14221 & 3575 \\
\hline Banca & - & --- & 7205 & 49862 & 7 & 54 & - & --- & - & - & 499 \\
\hline Billiton & - & - & - & - & 1 & 4.23 & 1319 & 24810 & - & - & 248 \\
\hline Borneo & - & - & 291 & 6429 & 18 & 134 & 634 & 12915 & 107 & 277 & 197 \\
\hline Moluccas & - & - & 275 & 8748 & 274 & 1431 & --- & - & - & - & 102 \\
\hline Bali, etc. & - & - & 541 & 9546 & 1292 & 7629 & - & --- & - & - & 172 \\
\hline $\begin{array}{l}\text { total Outer } \\
\text { Dist. }\end{array}$ & --- & --- & 10808 & 124605 & 3680 & 20583 & 52028 & 575550 & 6382 & 28902 & 7496 \\
\hline Total 1930 & 5 & 86 & 20304 & 316227 & 72521 & 262350 & 60458 & 652901 & 13917 & 45082 & 12766 \\
\hline Total 1928 & 5 & 100 & 19552 & 337012 & 81491 & 338628 & 70266 & 868348 & 14805 & 56879 & 16010 \\
\hline
\end{tabular}

1 thail $=100$ mata $=38.6$ gram; 1 ounce $=2.59$ thail .

All this points to a more profound context, the struggle between the colonial state representatives (like Baud) and the private entrepreneurship within their realm: the former do have the prerogative to define what is moral or immoral for whatever reason. This resembles the 'Staatsraison'

6 This table is given in the article of C. Steinmetz in: Indie en het Opium, p. 159. From the Outer Districts only a selection is given here. Therefore, the given total is not the total of the given districts, but of all Outer Districts. The totals of 1928 are derived from a table in Commission d'Enquête sur le Contrôle de l'Opium, vol. 1 p. 80 ff., vol. 2, p. 211 ff. 
of the highest state bureaucrats. In that case, the state knows perfectly well what it involves to distribute a substance like opium in a narco-military framework: it needs the money for its household and servants, and therefore its own activity is defined as of a high moral standing and its competitors as smugglers, enemies who should be eliminated.

Here we can provide another view on the relationship between the Outer Districts and Java plus Madura from several decades later, which results in new questions.

The first thing to deduce from the table is that in the Outer Districts in 1930, about 467 chests are consumed and in Java + Madura, about 328. This is more or less the same proportion as eighty years earlier (516 to $380) .{ }^{7}$ In this period, however, the population on Java increased from about ten million (around 1850) to 41 million (1930). In almost all other parts of Southeast Asia, there is a similar spectacular growth. ${ }^{8}$ The given data, provided by the Dutch Opiumregie, are therefore not very convincing, to say the least.

From this table one can learn many things, more about the Opiumregie itself than about - say - the degree of opium addiction in the population. In fact, the table contains data about the inhabitants of the districts and the average opium use per year of the several groups in those districts. As such, it symbolizes an important aspect of the opium monopoly: the ability to combine (and use) all kinds of information about the exploited subjects and the ability to define problems (dubious or not). The registration of five Europeans asking for and obtaining a license to smoke only 86 thails in a year is not only a demonstration of European "innocence and civilization" of the opium importers, but also of absurd state interventionism.

It is suggested that there were about 80,00o Chinese licensed and nonlicensed opium smokers in 1930 and 90,00o indigenous smokers of the stuff provided by the Opiumregie. A holder, however, is not the same as a user; he could be a dealer or shopkeeper, a non-smoking buyer or a family member. Furthermore, in the explanation one always used the Dutch

7 The Outer Districts total of 749,600 thails = about $28,942 \mathrm{~kg}=$ about 467 chests; the Java + Madura total of 527,000 thails = about $20,347 \mathrm{~kg}=$ about 328 chests. When comparing the several districts in the two tables, one is confronted with serious differences. This supposes, of course, that the reasonable guess of Baud about the smuggling in 1850 should be the whole consumption. This is certainly not the case, but also during the regime of the Opiumregie, statistics must have been used to cover government activities, because there was also a substantial amount of smuggling.

8 N. Tarling (ed.), vol. 2-1, p. 158. 


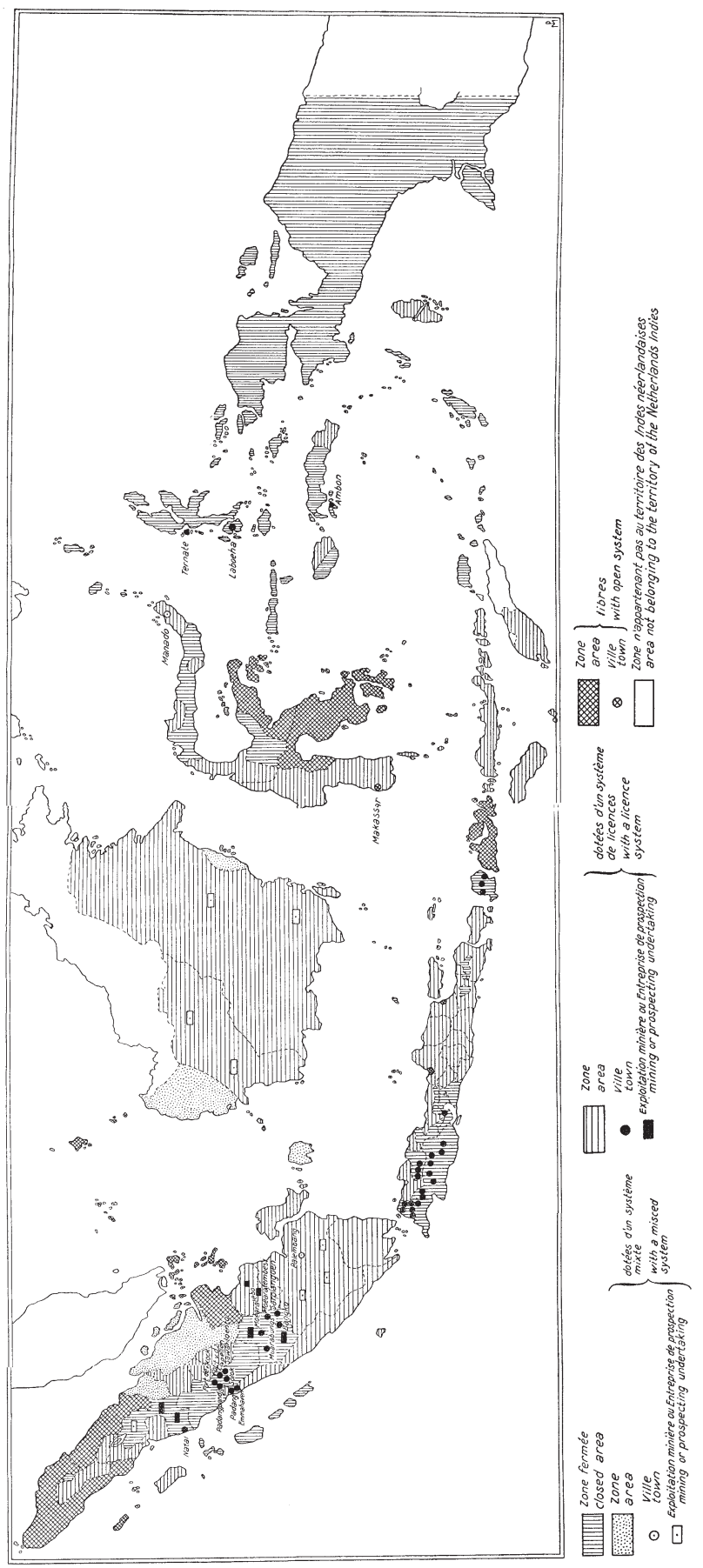

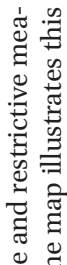

. 尽

ํㅜㅇ

을

Tे

ip

킁 :

है ठี

छ

రิ

융 ह

एँ

ن

छ त्र

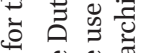

\&

옹

:

声菻

ส

:

क ई

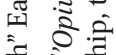

든

ปิะ

๑ :

Е

๑

胥

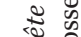

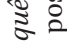

预

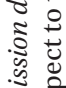

ई के

仓

ڤ 
word 'schuiver' for these "smokers", which was for most readers synonymous with addicts (see below). In addition, hardly any reader cared or knew something about the important difference between an opium eater and a smoker (the first consumes oin average much more morphine than the latter, etc.). Most commentators think that at least the same number of smokers were reached through the smuggling circuit.

The table gives the consumers of the legal opium (in Dutch: Wettig Opium). According to this, on average 1 in every 15 Chinese in the archipelago ( $7 \%$ of all Chinese) and 1 in every 684 indigenous inhabitant $(0.2 \%$ of all indigenous people) were smokers. In the Outer Districts this ratio was 1 in 10 Chinese and 1 in 1800 indigenous people.

There are specific districts in which the opium consumption is much larger than elsewhere. ${ }^{9}$ Officially, there were even districts without any smokers. A spectacular aspect invovles the $\operatorname{Ban}(\mathrm{g}) \mathrm{ka}$ district of the tin mines where $30 \%$ of all Chinese consumption can be noted. Some $30 \%$ of the Java consumption is concentrated in Eastern Java, etc.

If we try to define an opium addict in the 1930s, we can derive from the table that an average of 12 thail was consumed per Chinese smoker per year, while an indigenous man consumed almost 4 thail a year $(463.2 \mathrm{~g}$ and 154.4 g a year, respectively).$^{10}$ In other words, 1.27 gram and 0.42 gram a day, respectively. In terms of money, this consumption is calculated as follows:

Per head of the population in 1930, one spends 38 cents on Java and Madura for Opiumregie opium, in the outer districts 118 and in the whole of the archipelago 67 cents per year in a population of about 60 million souls' (italics added, H.D.). ${ }^{11}$

With these figures we can make a few interesting calculations to support our concept. First, the average of 67 cents paid in 1930 amounts to 40.2 million Dutch guilders earned by the Opiumregie or the state. The table provided by the Director of the Ministry of Finance, one of the most important figures in the Opiumregie, indicates the gross income for 1930 about 5 million less.

A second conclusion is that it is physically impossible to become an addict on 1.3 gram a day, let alone from 0.4 gram. To compare this, for

\footnotetext{
9 See map in J. Rush, p. 5 for a situation at the end of the 19th-century.

10 Suppose that the numbers in the table represent the consumers, which is suggested but not very convincingly. These Opiumregie figures, anyway, represent consumption of Opiumregie opium.

11 C. Steinmetz in: Indie en het Opium, p. 157, 158.
} 
instance, with a present packet of cigarettes of 28.3 gram (20 cigarettes) is rather complicated, because one has to compare the morphine with the nicotine content and their addictive effects. However, it is illustrative to say that Steinmetz' opium addicts smoke something similar to about 1/3 to one cigarette a day.

And what does it mean that one spends 38,67 or 118 cents a year on opium? The lowest ranks of the police earned at the time a maximum of 25 Dutch guilders a month; the so-called mantri-politie, specialized in attacking opium smugglers, earned double that amount. ${ }^{12}$ This is thus 300-60o guilders a year. If one earned the minimum and consumed the maximum of 118 cents on opium, this should amount to the negligible sum of $0.4 \%$ of the total annual budget (for a "coolie" with his yearly budget of about 180 guilders, it is still less than $1 \%) .{ }^{13}$

Caring about these "addicts" seems to be only an artificial case aiming at quite different matters than avoiding addiction. Therefore, one can easily conclude: the only explanation for all the fuss about the Opium Problem in the Dutch East Indies then is legitimating and securing a substantial financial contribution to the foundations of the colonial state through a well-known bad and controversial product.

This should have negated a major element of this Opium Problem: for middle- and upper-class well-fed consumers of opium, these quantities are not at all unhealthy for their purse or body. But the above calculations are averages of all classes, while we concentrate on specific users, their concentrations in the tin mines or their wanderings.

They are met, for instance, in chapter 8 about the Billiton Mining Company, a model for all work sites. Through the whole of the archipelago, hundreds of thousands of men and women were wandering between the many "white" plantations, mines, factories or cities. Between 1913 and 1925 about 327,000 contract "coolies" departed from Java alone for plantations and work sites in the outer islands. They were the opium clients and victims described as follows:

12 M. Bloembergen, p. 86. Elsewhere (p. 63) she states that household personnel (or 'the normal coolie') got 14-15 guilder a month plus free lodging; top police officers received 250-400 guilders a month.

13 The well-known economist J. H. Boeke studied household expenditures in 1886 and 1888. The lowest income was found in a small mountain desa, and he gave 3844 cents as the annual income for a family in which the man had to cultivate coffee for the government ( 78 times) and village services ( 72 times). In: Indonesia, p. 54 ff. The other examples given are interesting as well in this respect. 
Their wages were low (for women only half to three-quarters those of men), and what disposable income remained, men often spent on gambling and prostitutes; systematic indebtedness was a useful means for plantation managers to maintain their workforces. With appalling living conditions, disease was rampant, and death never far away ... To ensure a docile or at least compliant workforce, the plantation management could call upon the authority of the state, embodied in such legislation as the Netherlands East Indies Coolie Ordinances of 1880, 1884 and 1893 which imposed fines, imprisonment or extra labour obligations ... physical beatings and financial penalties ... ${ }^{14}$

A million poor people spending a few cents a year on opium will make a few people very rich, the statistics impressive, and allow the state to pay its police force easily to repress rebelling workers.

\section{The Bali Case}

It is appropriate to sketch the Opium Problem also from the perspective of a district instead of through the eyes of "Batavia" (Opiumregie). One example from the Outer Districts is Banca, on which were located $70 \%$ of all Chinese holders of an opium license in 1930, while on Billiton there was not a single one. Only Chinese non-license holders lived there, because it was at the time practically the private property of the Billiton Mining Company, which had its own opium policy.

A different situation existed on the island of Bali. There the Balinese nobility and princes dominated the scene rather than a Dutch company. As stated above, they had reacted to the Dutch opium import with the establishment of a true slave export already in the 17 th and 18 th centuries. In the 19th-century several factors led to important changes. ${ }^{15}$

Balinese slaves were no longer in demand, which was not due to a sudden abolition movement among the Dutch: instead, the Dutch state itself had started to colonize through strong military repression, and this procured cheap local labor. The imported slaves from Bali became too expensive. Raffles' anti-slavery and anti-opium ideas remained largely proposals; they had no relevant impact on the archipelago's economy.

14 See the contribution of Robert Elson in N. Tarling (ed.), vol. 2-1, p. 156, 157 .

15 H. Schulte Nordholt, p. 96 ff. It is not understandable why Clifford Geertz should be 'biased' in his opinion 'that opium was the main driving force of Balinese trade' because he referred to the 'conditions in northern Bali' only (see, Idem, note 35 p. 96). It can be expected that Geertz understood how the importance of opium remained as he indicated for at least half of the 19th-century, and changed afterwards as argued in my main text. 
Quite the reverse. He strongly facilitated the private English country traders who risked dealing with opium through Singapore, energetically supported by Chinese and Buginese traders. The Balinese authorities had soon discovered that their opium was much cheaper than the Dutch. In this way they compensated for the relative losses in the slave trade, but this must have given them little comfort.

A second source for cheap labor was also tapped by probably the same English, Portuguese (Macao) and Chinese opium traders: the "coolie" trade. And a third reason to gradually abandon the Balinese slaves-foropium trade was a natural disaster, the eruption of the Tambora volcano on a neighboring island (1815) which caused crop failures, a plague of mice and famine in the south of Bali.

The longer term effect, however, was that for about two decades fewer people could be spared for the slave trade, while in the subsequent period Bali became the 'chief granary for Singapore'. Rice-for-opium could replace the slave-for-opium trade, and in this transformation manpower in Bali became very important after $185^{\circ}$. In the north of Bali, a coffee-foropium trade gradually developed. ${ }^{16}$

The relations between Bali and the English Singapore with its many Chinese strengthened and, therefore, the influence of the Dutch weakened. Balinese leaders understood the shifting times and the changing importance of opium. They were

aware that the royal center should make an effort to increase control over the changing market, as indicated by ... monopolizing of opium imports and the additional taxes introduced with an eye to centralization of organized exports. ${ }^{17}$

The consequence of all this was that the use of opium penetrated more deeply into Balinese society in the second half of the 19th-century. Wiselius documents this as follows. ${ }^{18}$ From the Calcutta annual opium exports, 12,00o picul were destined for Singapore. According to the Annual Reports of the Dutch Consul-General in Singapore, the export from here to the "Netherlands-Indies" was on average 3,700 picul per year in the years $1878-1883$. Of this, $25 \%$ went to Batavia, $50 \%$ to Bali, and the rest to other ports. Wiselius stresses how strange it is that a Dutch consul knows of these practices and that nobody in Batavia protests against

\footnotetext{
16 Idem, p. $126 \mathrm{ff}$.

17 Idem, p. 102, 108 ff. Rochussen wrote in December 1847 also about opium activities of English merchants on Bali. See J. Baud, J. Rochussen, vol. II, p. $3^{20}$.

$18 \mathrm{~J}$. Wiselius (1886), p. 21 note 1.
} 
them, and the fact that every year about 3,00o piculs of opium are apparently distributed by "smugglers". That is double what the Dutch colonial government distributed to its opium dealers.

But the Dutch became increasingly angry about the more independent Bali and its wayward princes' orientation towards Singapore. As usual, they started wars. The first one (1846) led to the destruction of a palace, new contracts on Dutch terms, and quarrels between the Dutch and the Balinese decision-makers about what to do next.

The second war (1848) was a true Opium War, but less successful than the first English one of a few years earlier. It started when one prince 'put up defenses and bought large quantities of weapons and opium in Singapore'. ${ }^{19}$ This operation was an utter failure: the Dutch were heavily defeated, and strange Dutch stories were made up to explain this loss of prestige away. ${ }^{20}$

In the next war of 1849, the Dutch mobilized for their biggest military expedition with an army of 12,000 men under the command of an experienced general. Small successes were won for this army in the beginning, but it all ended in failure again. The general lost his life, surprise attacks by the Balinese cost many lives, 'unfamiliar conditions' and dysentery did the rest. A peace had to be concluded which the Dutch sold to "Batavia" and the homeland as a victory, but their defeat guaranteed an independent Bali for many decades to come.

The permanent mutual competition among the Balinese nobles was their Achilles heel. Some of them tried to strengthen their own position by asking the Dutch to support them (the enemy of my enemy is my friend principle). This led to two small military expeditions of the Dutch (1858 and 1868) against specific nobles, but the Dutch apparently did not dare to attack the whole island anew.

Until the end of the century, Bali even became more and more independent of "Batavia" in an economic sense. Buleleng, the main harbor in north Bali, developed into a prosperous and free port (no import or export taxes); non-indigenous merchants (Chinese, Buginese, Arabs, etc.) became more important and active.

19 H. Schulte Nordholt, p. 165 .

20 The most ridiculous story was that the Dutch commander did not dare to send reinforcements to Bali 'fearing that the revolution which swept over Europe in 1848 might spread to the colony' (Idem, note 24 p. 166). Another story only mentioned that the Balinese nearly lost this war because of 'lack of ammunition and opium' (Idem, p. 166). 
Particularly significant was the opium trade. Raw opium was imported in large quantities from Singapore, refined in Buleleng, and for the most part smuggled to Java. This lucrative smuggling ... attracted many Chinese immigrants who soon completely controlled the opium processing and trade. Part of the opium ... found its way to the Balinese hinterland ... The most important Balinese export product was coffee, the cultivation of which, concentrated in the central Balinese mountains, expanded rapidly. ${ }^{21}$

The opium trade was really booming. In 1861 opium imports were valued at 294,321 Dutch guilders; sixteen years later this had increased to the enormous sum of 4.5 million guilders, ten times more than the second largest import-textile goods. And so the importance of Buleleng increased, along the main trade route to Singapore; southern Bali became dominated by the opium-coffee part in the north.

In the last stage of the Dutch rule in the East Indies, probably the most devastating one, Bali also had to bear its share of what was officially called the Dutch 'Ethical Policy'. Along with Bali, the Dutch military machine tried to eradicate resistance in Aceh, Jambi, Southeast Kalimantan, Flores, South Sulawesi or Lombok. It did not take long before anti-Dutch revolts raged everywhere in the archipelago, and the last fully fledged war ended with the elimination of the colonial regime. Before that happened, hundreds of thousands of dead had to be mourned again.

The massacres in Bali (1901-1906) were part of this endgame. Opium again played a main role. First in the perception of the Dutch authorities, which claimed to have a

civilizing task which implied that "royal arbitrariness", slavery, and opium smuggling should be done away with. Governor-General W. Rooseboom formulated this vision as follows: "We ... shall, wherever there is injustice ... not be able to remain inactive in the protection of the weak and the oppressed. This is in complete accord with the ethical direction in colonial politics."'22

In several waves the Dutch army conquered Bali; many thousands of Balinese lost their lives; princes and nobles lost their influence; direct rule from "Batavia" became the punishment.

In the last military expedition to establish this lethal Pax Neerlandica, a royal 'resistance to the introduction of the colonial opium directive in April 1908' was crushed. ${ }^{23}$ In other words: this Opium War was waged to

\footnotetext{
21 Idem, p. 169 .

22 Idem, p. 210.

23 Idem, p. 215.
} 
establish the Opiumregie and its opium dens in Bali and to eliminate the so-called "smugglers"; the competition to the Dutch opium dealers had to be eradicated, not the Dutch opium business. That was the 'civilizing task'.

The table 14 demonstrates the effects of these massacres: Bali became the Outer District with the most indigenous holders of an opium license and nearly $30 \%$ of all opium consumption! Apparently, the traditional Balinese resistance against the Dutch disappeared in the opium smoke. This tactic was known among the many enemies of the Dutch kafirs like Muslims in Aceh. They told followers there in 1928 that the Dutch tactic to disarm their enemies was executing

the following scheme: they introduce gambling and opium-smoking, and some set themselves up as toll-collectors as in Java. With great devotion they encourage the people to gamble ... They make the law, the damned kafirs, and they rule with new methods. ${ }^{24}$

An important instrument to manage this is the subject of the following paragraph.

\section{The Opiumregie 25}

The man who after much commotion ultimately prepared the decision to transform the opium farming 26 "system" of the Dutch into a centralized state bureaucracy, the Opiumregie, was Willem Pieter Groeneveldt (18411915). At that time his was a rare intellect with a long and interesting career in East Asia, starting as interpreter for Dutch embassies in Canton and Peking, writer of a scholarly book about the Malay archipelago, and ending as vice-president of the Board of Netherlands Indies, one of the highest functions in the Dutch colony. This man was sent to the French colonies (Cochinchina, Tonkin or Cambodia) to study the French experience with a similar transformation in the opium management. His clear and extensive report with many quantitative data was a long and well

\footnotetext{
24 Document from 1928 reproduced in Indonesia, p. 211, 212.

25 For the following, see the 1890 advice of W.P. Groeneveldt, who studied the French Opiumregie in Indochina. See also J. Rush, chapter 11 and the "War on Opium" (chapter 10), which allegedly triggered the Opiumregie. E. Vanvugt (1985), p. 269-377 gave a very detailed and relevant description of the establishment and activities of the Opiumregie. M. de Kort, p. $45 \mathrm{ff}$.

26 For more details about the opium tax farming in the East Indies and Southeast Asia (except in this section), see below in ch. 23 .
} 
argued plea to take the step to a centralized system (see ch. 23). His arguments in favor of the Opiumregie can be summarized as follows. ${ }^{27}$

First try out the new system in Java and Madura before introducing it elsewhere in the archipelago, but do not establish a pilot project on, for instance, the island of Banka. Such a project delivers no other experience, as already known in Cochinchina. If one can experiment in a region as large as part of Java, then one is surrounded by leasers whose existence is threatened. Failure cannot be avoided. Like the French dared to do in Cochinchina, the Dutch must act firmly in the East Indies.

An Opiumregie depends first and foremost on a strong opium police at sea and struggling against every form of opium smuggling on land. The police cannot handle this task alone, they must be embedded in a network of district police, customs offices and the Ministry of Finance. This proposal led to a modern way of fighting criminality. These measures 'must not have been perceived as favorable to the leasers ... Where the monopoly is in the hands of the Government ... it should be an honor for everybody to cooperate ...'

Nothing changed regarding the purchasing of the raw opium in Benares or elsewhere, except that this could be done much more cheaply, as proved in Cochinchina.

In the technical part of his proposals, Groeneveldt criticized Struick (Haak and Wiselius) for not understanding the way raw opium is treated to obtain tjandoe (prepared opium). The main suggestion was to establish a centralized production in an opium factory in Batavia. This happened about ten years later.

Apart from the factory-produced tjandoe, there is an indigenous kind, called tiké (tikeh). This is raw opium mixed with pulverized awar-awar leaves:

The minor quality of this second kind of tjandoe derives from the preparation in which a substantial quantity of sugar is mixed in and during the remainder of the cooking is treated with lemon juice to extract all the morphine out of it. In this way ... one gets 12 to 17 thails per catty raw opium, whereas with the normal tjandoe one gets only 10 to 11 thails. ${ }^{28}$

27 W.P. Groeneveldt, p. 127-139; the quotations come from these pages. See also J. Rush, p. $208 \mathrm{ff}$. although Rush uses the wrong title of G.'s publication. Rush much prefers the small pamphlet by N. Struick, published a year before Groeneveldt's large analysis. For the whole discussion for and against the Opiumregie, one has to read Rush's chapters 10 and 11.

28 Idem, p. 129. See for the tikeh production Appendix 5 . 
If the morphine is gone, opium addiction seems impossible (see Appendix 5 for morphine content).

Another theme of Groeneveldt's proposal was the packing policy of the opium: one has to exercise "direct mail" as far as possible, avoiding middlemen who increase the price and reduce the quality. The main argument against middlemen (and, therefore, against the whole farming system) is in fact 'that through the use of middlemen, a large part of the advantages given by the work of the Regie is lost ...'29

To sell directly to the users, one has to provide the smallest quantities. In Cochinchina it had been discovered that even deliveries of $20 \mathrm{~g}$ (about $1 / 2$ thail) were too large. Furthermore, the opium dens were gradually transformed from locations to consume into places to buy the stuff. Consumption took place largely outside the dens, except when smoking could be combined with prostitution. Anyway, this led to the conclusion that a rather normal consignment of 1200 pikul $(=75,000 \mathrm{~kg})$ raw opium bought in Bengal by the government had to be sold to the consumers as 120 million small boxes of a few grams (mata). Groeneveldt proposed making small tubes of tin or copper for these small quantities. (It became lead and a battery of filling machines entered the opium factory.) These tubes carried specific marks so that the consumer could not be cheated.

The Opiumregie became the bureaucratic machine to execute the government's opium monopoly. Historically, it is a variant or an extension of the monopoly established by the government after it took over the heritage of the VOC, which was already based on a specific monopoly management. Now the farming system present until 1894 was modernized and industrialized: a very modern opium factory was opened in 1902, and the opium business became a 100\% government task.

In the period that the colonial bureaucracy decided to establish an Opiumregie, the Dutch state earned no less than 14 million guilders per year (1896-1898) which was the largest source of income after the land rent (ca. 17 million). ${ }^{30}$ Of course, bureaucrats complained that this was too small and claimed out of the blue that this income had to follow the population increase: in the last few years the population had increased by $4 \%$ and the opium income by only $0.6 \%$; it doubled every 42 years. Production, distribution, administration or anti-smuggling measures, all this and more had to be rationalized, automated and so on.

\footnotetext{
29 Idem, p. 136.

30 According to a document published in 1901 in Indonesia, p. 59 ('rents on opium' and 'opium monopoly').
} 
Many new laws had to be designed which also transformed life in the colony (for the juridical side of the Opiumregie, see below). Retailing was forbidden outside the 1100 opium dens managed by the Opiumregie. As stated, the tjandoe got a specific and obligatory packing in the opium factory. Once opened, these tubes were difficult to close; specific marks were made on them so that fraud could easily be detected (see for details appendix 5$)^{31}$

It took about fifteen years before this Opiumregie functioned rather smoothly throughout the archipelago. The leadership always denied that this new institution aimed at increasing opium consumption. But Groeneveldt was clear in his secret report:

The Regie with exclusion of everybody else aims to satisfy the opium needs. There is no reason to complain about this relative to the sheer extent of this task, because it did not create this need ... if it did not fulfill this task ... important centers of consumption would have to rely on smuggling ... In the system of the Opiumregie, there is no place to reduce the quantities which could be sold; it is necessary to help every buyer. ${ }^{32}$

For the publicity, of course, one cherished the hope that the closest possible management of all elements of the opium problem, like in a police state, would solve this problem in the long run and, therefore, should drastically discourage consumption. How long that "run" should be was not disclosed, but it was clear to all from the beginning, except these bureaucrats' publicity, that this expectation was pitched too high. "On purpose", argued the opposition. Anyway, the first more or less independent investigation into the matter was crystal clear about the Opiumregie's legitimation to act as it did:

This conclusion [reduction of consumption, H.D.] is not supported by the Colonial Reports, which show that the use of opium in Java has increased from 735,00o thails in 1904 to 870,000 thails in 1912 in spite the closingdown of a considerable number of shops and dens ... ${ }^{33}$

In January 1934 the Opiumregie was extended by the Saltregie (Zoutregie). With 'salt' was meant not only kitchen salt, but also 'salts and other derivatives from morphine, diacetylmorphine and cocaine'. ${ }^{34}$

31 A specific ordinance was issued for the packing of the regie opium: see Opium- en Zoutregie, p. 57-64 with a very detailed description of an opium tube in articles 3 and 4 .

32 W.P. Groeneveldt, p. 137.

33 Document from 1914 reproduced in Indonesia, p. 88.

34 Opium- en Zoutregie, p. 12. See also Idem, p. 93 ff. 

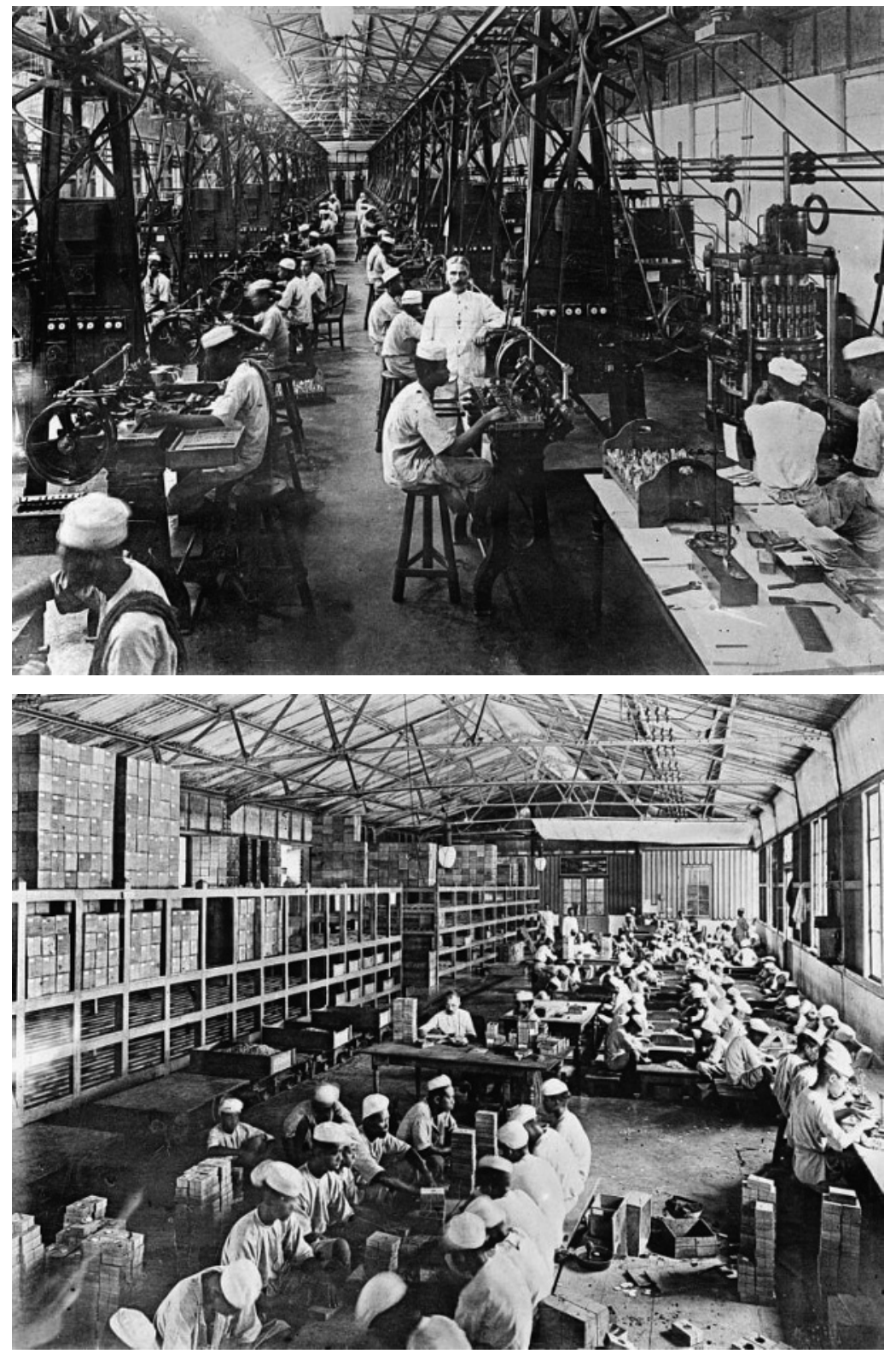

Ill. 18. Interior of the Opium factory, Batavia ca. 1935

Source: Collection Royal Tropical Institute. In the first hall the opium is pressed into small metal capsules of several sizes. The second picture shows the hall in which the opium capsules were packed in wooden boxes (for the details see Appendix 5). 
Steinmetz, head of the Opiumregie in the 1930s, wrote:

The existing penal law relative to the import, manufacturing, consumption and distribution of opium, morphine, morphine preparations and derivatives, used for other than medicinal purposes, is being tightened up, and new rules were announced for cocaine, eucaine and other narcotics. ${ }^{35}$

This monopoly combined not only trade, refining and distribution using a factory and about 1100 distribution centers in the whole archipelago. This control system of everything and everybody included a rather substantial police force to attack "smugglers", etc. and covered also the private lives of the consumers. So, the official bookkeeping of 1927 revealed that there were 177,122 opium addicts in the archipelago $(92,873$ indigenous people; 83,242 Chinese and only 7 Europeans). For cocaine see below.

The Opiumregie became, symptomatic enough, a department of the Ministry of Finance. This immediately resulted in the criticism that the profit of the Opiumregie landed in the state's coffer with all its consequences for the eradication of the opium addiction: the more addicts, the better for the colonial state finances. As we have seen, that was indeed the standard practice, motivation and rationale behind all measures.

The highest bureaucrats of this Ministry were never tired of explaining that 'the Opium monopoly in Dutch East Indies has in principle [in wezen] not a fiscal but a social aim ... the maximum limitation of the use of opium ...' after which another 15 rules follow which contradict this announcement with several "if's". 36

Even during the International Conference of Shanghai in 1909, the Dutch government had to defend itself with a specific declaration that it 'will never refrain from taking measures ... to minimize gradually the use [of opium] on financial grounds ...' It had envisaged a period of about fifteen years before a definite prohibition could be declared.

However, it then declared that this period cannot start because the poppy-producing countries (British India, etc.) were not ready to take this step. The British replied, of course, that countries like the Dutch East Indies were not ready to start that famous period. As a result, nothing changed, although to everybody's surprise the Chinese government succeeded in eradicating the opium production in Szechwan or Yunnan to a substantial degree; an embarrassment for the British, Dutch, and French and their opium production facilities.

\footnotetext{
35 C. Steinmetz, director of the Opiumregie, in: Indie en het Opium, p. 149.

36 C. Van den Bussche, director of the Ministry of Finance, in: Idem, p. 117.
} 
Another main criticism of the Dutch concerned the extremely high price the government asked for its opium; a price which increased in 1926 to the highest level in East Asia (and, therefore, in the world) of 30 Dutch guilders per thail (=38.6 g). The following table is given to support the government opium policy. It has to prove that there is no fiscal aim of the opium policy: the opium profits never pay for more than $7 \cdot 3 \%$ of the normal expenditures of the colonial state.

Table 15. Income and Expenditures of the Opiumregie and the Colonial State, 1920-1931 (x 1000 Dutch guilders) ${ }^{37}$

\begin{tabular}{lclccc}
\hline Years & $\begin{array}{l}\text { Gross income } \\
\text { Opiumregie }\end{array}$ & $\begin{array}{l}\text { Income for } \\
\text { the ordinary } \\
\text { service }\end{array}$ & $\begin{array}{l}\text { Income for } \\
\text { the extraordi- } \\
\text { nary service }\end{array}$ & $\begin{array}{l}\text { Normal } \\
\text { expenditures } \\
\text { of the state }\end{array}$ & $\begin{array}{l}\text { Column } 3 \text { in } \\
\text { \% of column } \\
5\end{array}$ \\
\hline 1920 & 53640 & 42671 & 4 & 5 & 6 \\
1921 & 53318 & 43471 & --- & 672982 & 6.3 \\
1922 & 44220 & 35098 & --- & 586740 & 7.3 \\
1923 & 37583 & 31061 & --- & 514054 & 6.8 \\
1924 & 35317 & 28494 & --- & 440801 & 7 \\
1925 & 36640 & 28755 & --- & 408024 & 6.9 \\
1926 & 37727 & 29471 & --- & 421110 & 6.8 \\
1927 & 41617 & 24955 & 6582 & 472726 & 6.7 \\
1928 & 42871 & 25727 & 8828 & 510213 & 5.2 \\
1929 & 40982 & 26200 & 6939 & 514993 & 5 \\
1930 & 34599 & 26921 & 564 & 523995 & 5.1 \\
1931 & $26000 *$ & $21000 *$ & --- & $532288^{*}$ & 3.9 \\
\hline
\end{tabular}

* Only a half-year estimate

Government sophistry was extreme: the price increase could be a way to avoid smuggling, although the obvious rule was that the higher the official price, the more smuggling was encouraged. Is it not so that

the geographical position of the archipelago makes it less vulnerable to smuggling'38; the smokers are accustomed to this price, so we can keep it like this ${ }^{39}$; if all our anti-smuggling measures are not successful, we still can decrease the price; the international situation has been changed in such a way 'that it is not necessary to consider a reduction for the time being'. ${ }^{40}$

37 Data provided by the Opiumregie in the article of C. Van den Bussche in: Indie en het Opium, p. 118.

38 Idem, p. 120.

39 Idem, p. 121.

40 Idem, p. 121. 
All this was an answer to an increased anti-opium sentiment and action in the motherland. That was in fact a reason why the Dutch copied the system of a $100 \%$ government monopoly of their main competitor in the realm, the French.

Steinmetz himself mentions price increases on Celebes from 3 guilders in 1926 to 30 guilders in $193 !^{41}$ In short: no reduction of the price following the normal fiscal aims, increased smuggling, increased corruption among the top bureaucrats. As a last defense of its policy, these officials attacked their critics and the public opinion with the "argument":

... it is also important to realize the correct appreciation [of our opium policy], because the wrong understanding of this policy and the specific suggestive effect of the criticism, we should only follow fiscal aims, ... only supports the wild prohibitionists, ... so that we, in the end, have to abandon our careful and efficient anti-opium policy. ${ }^{42}$

These "prohibitionists" were several kinds of anti-opium lobbies in and outside the Dutch East Indies as, for example, in the USA, including officially the US government. Happily, the many critics of the government policy were not impressed, as will be demonstrated in the next chapater. One example comes from Herbert L. May. He conducted a survey of opium smoking in the Far East (report 1927) and became a member of the League of Nations Permanent Central Opium Board; in short, an expert in the right place. This man concluded:

Existing government prices most everywhere are too high, however, especially in the Netherlands Indies. Not only do they encourage smuggling, but they constitute a high penalty against the man who obeys the law by buying government opium and a high reward for the one who buys smuggled opium at the much lower price. Divans (public smoking establishments) apparently have a social feature which makes smoking more attractive. Therefore, since the object is to reduce or stamp out the vice, divans should not be permitted. ${ }^{43}$

This colonial state with its always growing social and political unrest was constantly in need of large amounts of money, while the motherland was always unwilling to spend more on its colony. To be more specific: the motherland expected the colony to pay for itself and provide in addition

41 C. Steinmetz in: Idem, p. 150.

42 Idem, p. 122. Other "official" contributions to this interesting reader come from the head of the Opiumregie (Steinmetz), a Director of the Opium Factory (Buck), who explains the working of morphine on the mind or from a Chief of the Opium police.

43 Quoted in A. Vandenbosch, p. 283. 


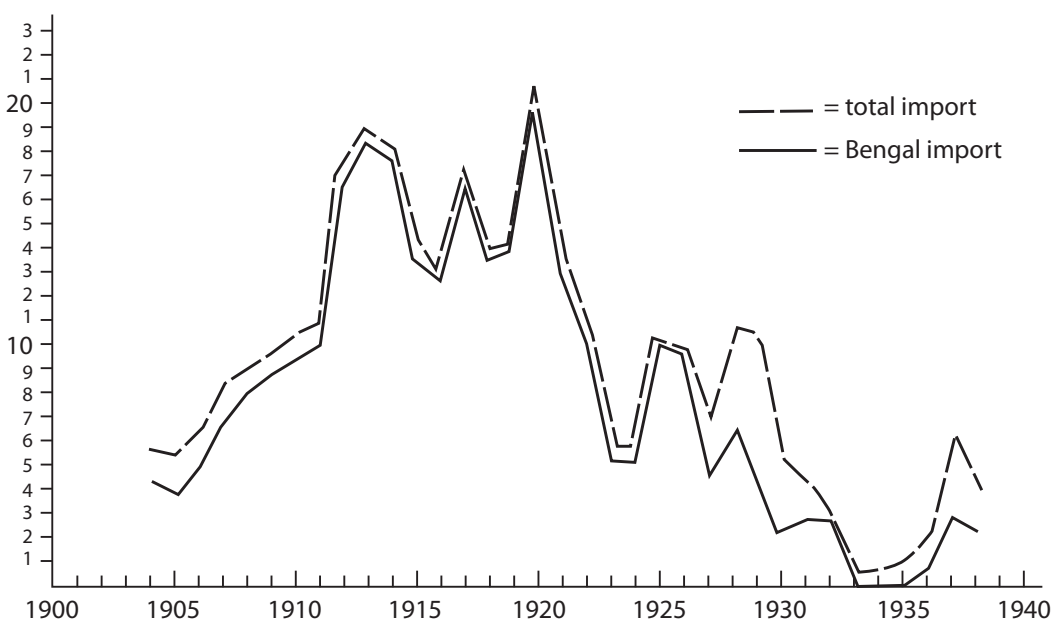

Figure 6. Opium Factory, import raw opium, 1900-1940 (x 10,00o kilogram)

Source: H. Derks based on the Year Accounts of the Opiumfabriek, the Opiumregie and of the Opium- en Zoutregie (Batavia, 1913-1938).

raw material for the home industry, a market for its end-products and a place for the recruitment of a rich Dutch bureaucratic and military elite, including a substantial financial contribution to the welfare of the greedy motherland.

This lead to serious competitive pressure among the top bureaucrats for personal gains in the intentionally criminalized opium scene. In 1923 one of the highest police officers in the colony was arrested because he had carried out fraud for the enormous sum of one million guilders; a head of the criminal opium investigation department was accused of opium smuggling; another was dismissed for being a morphine addict; others blackmailed Chinese brothels, etc. for an amount of 2,000 guilders a month, etc. ${ }^{44}$

Fabulous amounts of money in the colony circulated "underground", as was usual in the period of the VOC. One can safely conclude that the whole opium business of the Dutch during the forty years after 1900 yielded at least a profit of close to 1-1.5 billion guilders (current value. This level of profit was never reached with the other narco-activity.

44 Idem, p. 227. The official monthly salary was about 500 guilders. 


\section{The Dutch Cocaine Industry}

The narco-military activities of the Dutch were unprecedented. Apart from opium and its whole infrastructure, including an opium factory, the Dutch government also strongly facilitated the production of coca leaf and co-financed at least two cocaine factories, one in Amsterdam and later another in the colony. These activities started at the same time as genocidal wars were waged against people in the Outer Districts, who once again were fighting for their liberation (Aceh, Bali, Lombok, etc.).

In the Annual Accounts of the Opiumregie, information about the cocaine factory and its activities in Java is given in passing as if it was unimportant:

Concerning the cultivation of the coca and the use of coca leaves by the population, there exist no other peculiarities than given in the previous report ... The plant is grown only on Java on a scale of about 1600 hectares. Not included are cultivations along roads, in hedges, etc. In 1923 the total production of coca leaves was 922,866 kilogram; the exported quantity was 907,335 kilo. (italics added by me, H.D.) ${ }^{45}$

This Annual Account also tells us something about prices and export destinations. The prices of the leaves varied from 6o to 160 Dutch guilders per picul (= here $60.5 \mathrm{~kg}$ ) according to the cocaine content. Although most of the export was destined for the cocaine factory in Amsterdam, the Japanese were becoming more active buyers. They even bought a whole Java harvest for a fixed price of 75 guilders per picul without any guarantee of the cocaine content (1923).

Table 16. Coca Leaves Export from Java, 1904-1940 (selected years) ${ }^{46}$

\begin{tabular}{lccc}
\hline Year & Coca leaves in kg & Year & Coca leaves in kg \\
\hline 1904 & 25836 & 1924 & 1118000 \\
1906 & 122000 & 1926 & 1043000 \\
1908 & 417000 & 1928 & 385000 \\
1910 & 430000 & 1930 & 354000 \\
1912 & 1075000 & 1932 & 209000 \\
1914 & 1353270 & 1934 & 105000 \\
\hline
\end{tabular}

\footnotetext{
45 Opiumregie (Verslag, 1923), p. 36.

46 From the article of Paul Gootenberg in: S. Topik et al. (ed.), p. 334. Here only a selection of his data is given. See also L. Lewin, p. 105-109.
} 
Table 16. Continued.

\begin{tabular}{lccc}
\hline Year & Coca leaves in $\mathrm{kg}$ & Year & Coca leaves in $\mathrm{kg}$ \\
\hline 1916 & 407984 & 1936 & 125000 \\
1918 & 661968 & 1938 & 50000 \\
1920 & 1676621 & 1940 & 125000 \\
1922 & 1283503 & & \\
\hline
\end{tabular}

The total export of coca leaves from Java in these same years was not less than 21 million kilograms. The minimum price of 100 kilo was $5^{0}$ guilders, so that in these 40 years there was a turnover of some 10 million guilders in coca leaves only. But apart from leaf production, there was also cocaine production. The price of leaves was coupled to the price of cocaine: for one kilo of pure cocaine, one needed 123.56 kilo of leaves. ${ }^{47}$ This means that not less that $170,000 \mathrm{~kg}$ cocaine could be made from the total Dutch leave export alone.

The value of this cocaine can be estimated as follows. In 1884 the Dutch journal for the medical profession was very positive about cocaine: the only disadvantage was the price of 9,00o Dutch guilders for one kilo. ${ }^{48}$ This leads to a turnover of 1.53 billion Dutch guilders! Of course this is the theory. It indicates, however, in which level of money market cocaine business has been arrived after 190o. It learns, furthermore, that the available government statistics must be taken with many pinches of salt; they all strongly underestimate - on purpose or not - the relevant levels of production or profit.

The rapid rise of the Dutch on the world cocaine market took the established parties like the Peruvians by surprise. From 26 tons in 1904, production immediately soared at a tremendous pace. The reason behind this spectacular growth was quite simple. First and foremost, the combination of an effective colonial production of raw material for a cocaine industry in the homeland, a willing state bureaucracy and enough private investors, also partly channeled through state-sponsored banks like the large Dutch Colonial Bank. When expansion and success were apparent, the Dutch diplomacy in the international negotiations to prohibit the drugs

47 Quite different figures are mentioned, but the most reliable in this respect seems to be the Dutch expert A.W. de Jong, p. 885. After an analysis of the German, British and American leave - cocaine ratio De Jong concluded: 'The quantity of coca leave necessary to produce $3,480 \mathrm{~kg}$ cocaine is, therefore, about 430 ton.'

48 M. de Kort, p. 39. 


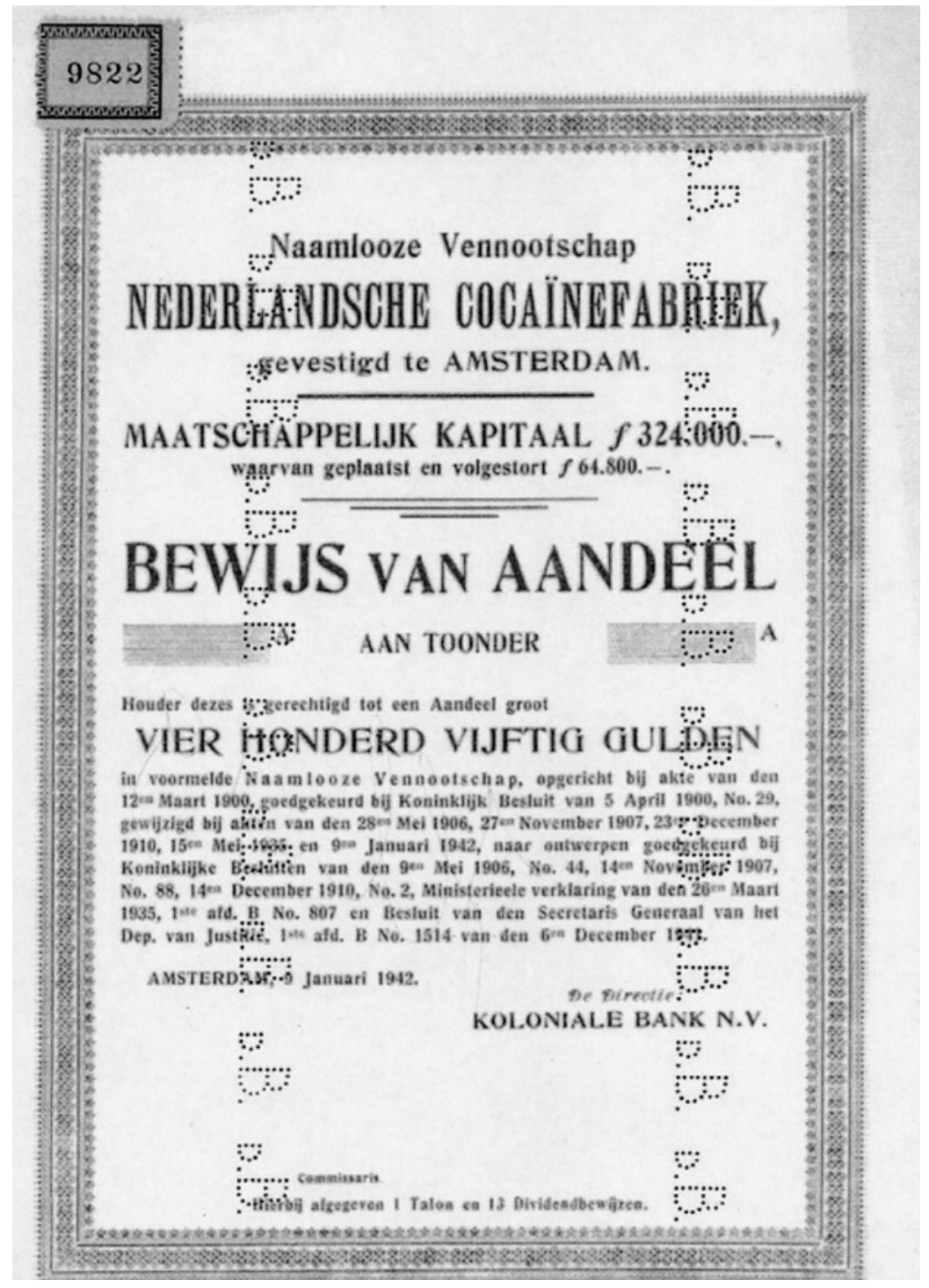

Ill. 19. Dutch Cocaine Factory, copy of a share, 1942 Source: www.deresearcher.nl

business was very willing to slow down the American anti-drugs policy ("prohibitionists") and the private anti-opium leagues. This game was played together with the British, who had similarly large drug interests. 
There was no Cocaine-Regie imposed as in the opium case and, therefore, no cocaine monopoly system. The formal reason was that this enterprise was a private one, established by the Colonial Bank, property partly of the Dutch royal house. Therefore, it was not a clearly capitalist private business either, let alone a prerogative of some mafia, as was clearly the case a few years later. In the research, raw material and distribution side of this cocaine problem, the Dutch colonial state was dominant or, at least, very helpful with its experienced, bureaucratic drugs infrastructure and opium money.

Cocaine production involves a much more sophisticated chemical process than opium, and had to be managed by a European and American pharmaceutical industry. Famous names such as Boehringer (Germany), Hoffman-La Roche (Switzerland), Merck (Germany, USA), BASF (Germany), Rhône-Poulenc (France), etc. were all heavily involved in cocaine production and distribution. This was because they had in the meantime (from about 1870) gained experience with the production of the opium derivatives, morphine and heroin. In this cocaine scene the Dutch played again a major, sometimes the most important, role.

The cultivation of coca plantations on Java began around 1885 when the relevant botanical experiments spread among several European colonial powers. It was a stroke of luck for the Dutch that their special variety of Erythroxylon novogranatense contained twice the cocaine content of the usual Peruvian kind. Dutch botanists had done a "good job" in the well-furnished gardens of Buitenzorg.

Parallel to the Opium Factory, a Cocaine Factory was established, first in Amsterdam (1900). ${ }^{49}$ It used patented German technology (Farbwerke) to extract cocaine from coca leaves imported from Java. It furthermore enjoyed the advantage of the well-organized plantation systems in the Dutch colony: cheap Asian labor, four annual harvests, economies of scale, intercropping with colonial rubber and tea. The performance of this cocaine industry impressed foreign investors so much that even Merck USA started its own coca plantation on Java with great success in the 1930 .

The Nederlandsche Cocainefabriek (NCF) became the largest in the world. It even created a new product, novocaine, a fully synthetic sub-

49 The fate of this factory became recently subject of a highly interesting movie by Jeanette Groenendaal, The Dutch Cocaine Factory (2007) and of a novel by Conny Braam (2009). 
stitute for cocaine. It was a less poisonous drug than cocaine with more or less the same vein-constricting effects; as such, it was considered more suitable for the dental practice. Nowadays, it has been replaced by more effective drugs. This activity in Holland triggered other initiatives there. It is not surprising that one of them, the Chemische Fabriek Naarden, soon became involved in obvious mafia practices of smuggling morphine and heroin to China. ${ }^{50}$

Almost as quickly as it arose, the Dutch position in this market vanished. In particular, the decline was very fast after 1925. The reasons for this are partly obvious: the international competition strongly increased, and governments made agreements like the Geneva Convention (1925) to restrict the business to trade for 'medical and scientific purposes'. Just before implementing this system, the Dutch sent a million kilograms of leaves out from Amsterdam warehouses. ${ }^{51}$

As can be seen in the table, during First World War and the Great Depression, the demand for cocaine collapsed. That is contrary to the persistent legend that European soldiers were doped with cocaine to fight longer and better: cocaine has always been a peacetime product, a luxury for those who can afford it. ${ }^{2}$ There are obvious reasons for this: the deliveries are hindered in wartime, although the demand may increase; the price for an individual portion may be sky-high in Europe, but the price for a total harvest of leaves dropped sharply.

In the following table the Dutch disadvantage (?) is shown from a different angle: the geo-political position from its huge stocks of coca leaves.

Before World War I there were cartel-like arrangements between the largest European cocaine manufacturers which guaranteed the highest prices. But even in Holland there were three cocaine factories competing with each other. After the war each manufacturer had to manage its own business, with the result that the competition strongly increased and prices fell, despite a growing demand. ${ }^{53}$

In one of its last massive reports (before the Second World War), the Central Opium Board (League of Nations) assessed the drug traffic,

50 M. de Kort, p. 98-110; M. de Kort in: P. Gootenberg (ed.), p. 140.

51 Idem in: Idem, p. 131.

52 Although not so unequivocal as in the Java statistics, the Peruvian exports with a different market show the same trend for the World Economic Crisis of the 1920 s and also for the whole World War I period of 1911-1919. Remarkable are also the fluctuations in the US coca imports during World War II. See S. Topik et al. (ed.), p. 338 and 342.

53 M. de Kort in: P. Gootenberg (ed.), p. 130. 
Table 17. Stocks of Coca Leaves, 1933-1938 (x 1 kilogram) ${ }^{54}$

\begin{tabular}{lrrrrrr}
\hline Country & 1933 & \multicolumn{1}{c}{1934} & \multicolumn{1}{c}{1935} & \multicolumn{1}{c}{1936} & \multicolumn{1}{c}{1937} & 1938 \\
\hline Germany & 56200 & 50247 & 52250 & 39400 & 45424 & 72862 \\
United KIngdom & 17625 & 313 & 9391 & 9909 & 6689 & 11465 \\
United States & 204 & 191 & 203 & 197 & 197 & 197 \\
France & 32613 & 11781 & 15556 & 31370 & 46446 & 59374 \\
Netherlands & 577825 & 541120 & 462191 & 391456 & 331357 & 136508 \\
Switzerland & 21931 & 310 & 10390 & 251 & 2740 & 2619 \\
\hline
\end{tabular}

production and consumption of the new products as follows. ${ }^{55}$ The gradual decrease in the manufacture of the three main drugs - morphine, heroin and cocaine-stopped: the first increased by 11.5 per cent, the other two showed a slight increase. However, as concluded above, the consumption in this time of crisis decreased by 10 per cent for the second drug and 4 per cent for the other two.

The increase in morphine production occurred mainly in the UK (from 1,292 kilo in 1932 to 1,873 kilo one year later); cocaine also increased (from 238 kilo in 1929 to 427 kilo in 1933). The main producer of morphine was the US with 7,459 kilo in 1933, while Japan manufactured most of the cocaine (920 kilo). In this last country, the consumption of cocaine was also the largest (14 kg per million inhabitants). In Europe, the largest cocaine consumer was France ( $9 \mathrm{~kg}$ per million).

The history of the NCF continued: apart from new products such as novocaine, it also started with already well-known products like codeine, benzedrine (amphetamine) and efedrine. From 1932 onwards it even began processing raw opium into morphine. ${ }^{56}$

There was, however, no future for Dutch cocaine anymore: in the same year the dry coca-leaf production of Peru had already reached the 3,500 tons with an export of 85 tons; in the other South American production country, Bolivia, plantations with a surface of 8,333 hectares produced 1,735 tons and exported 347 tons of dry leaves. ${ }^{57}$

54 A.W. de Jong, p. 885. It is nearly for sure, that at least the USA figures are a bit misleading: such small stocks of leaves do not have any value for the preparation of raw cocaine. It is not sufficient for Merck alone. This besides the fact that the USA has several much more important South American coca leave sources. The value of the table is mainly to show the relative importance of the Dutch position.

55 I used here the summary in the Newcastle School of Medicine Centenary, Oct. 13, 1934, p. 686.

56 For the following I used information from the National Archive, The Hague, De Nederlandsche Cocainefabriek (12-3-2010).

57 A. W. de Jong, p. 870, 871. 
While the relationship with the Dutch state had mostly been an indirect one, this gradually became a direct one. During the occupation in World War II, the NCF was fully incorporated into the German war economy. Poppies had to be planted in Holland to obtain enough raw opium under the direction of a Department of Medicines. The growers were told that the morphine extracted from the poppies was only destined for 'own land and Volk', which was untrue. Only those produced in the province of North Holland remained in the Netherlands; the production in all other provinces went to Germany.

The profit construction of the NCF was unbelievable: it received 165 tons of raw material for free, and it could charge its processing costs to the state. The price to be paid was that end product of raw opium became state property. Then the NCF bought the raw opium from the state to produce pure morphine and other derivatives from it. The transaction price of 130 guilders per kilo of raw opium was far below the cost price, so that the NCF realized fabulous profits on its morphine during the war. Soon after the war AKZO Nobel bought the company for an unknown price.

\section{Legal Hypocrisy}

One may conclude, relative to the East Indies drug position, that there was no reason to complain about the substantial and profitable opium and cocaine business. But Steinmetz, head of the Opiumregie in the 1930s, wrote:

The existing penal law relative to the import, manufacturing, consumption and distribution of opium, morphine, morphine preparations and derivatives, used for other than medical aims, is tightening up, and new rules are being announced for cocaine, eucaine and other narcotics. ${ }^{58}$

The latter was never realized, and the penal side of the problem never received an adequate treatment.

Still, with the establishment of the Opiumregie, opium factory or cocaine factories, the colonial government had to provide some legal framework to regulate the production or distribution of narcotics: the government of the homeland urged the colony to pay for itself. It was, however, also obliged to minimize the consumption of narcotics or eventually to warn and save the citizens from them: the public and religious

58 C. Steinmetz, director of the Opiumregie, in: Indie en het Opium, p. 149. 
opposition against governmental opium distribution in the homeland had to be satisfied. In short, in practical and moral terms, these aims were conflicting and the involved interests clashing.

The result is legal hypocrisy: suggest doing one thing, but try to realize the other. As all colonial governments were far from democratic, they played this hypocritical game only superficially. Even the fear of repercussions in the Dutch homeland was bearable. The representative of the mightiest economic power in the colony, Royal Dutch Shell, was Dr. Hendrik Colijn, the Calvinist and colonial military butcher, who had been a homeland-politician and prime minister until the Second World War.

It is a major reason why the most remarkable clashing interests were all within the colonial government itself: to pay for the costs of the colony (to put it as broadly as possible), opium was a most suitable product from the very first time Dutch merchants and the VOC arrived in the archipelago.

In the twentieth-century the situation was still the same: more consumers, more addicts were needed; the distribution should be better organized, and so on.

As everybody knew at the time, including the members of the many International Opium Conferences, this conflicted with the aim to eradicate the opium habit. The word consumption cannot be found in the relevant legal texts, let alone some ordinance devoted to the subject of how to diminish opium consumption. Only regulations to better organize the production and selling to get as much financial benefit from the investments as possible.

The clash within the Dutch colonial government was well documented by Wim Wertheim. In the 1920 s he was a young legal adviser to the Dutch colonial government. ${ }^{59}$ For his own boss, the Minister of Justice, he had to design new, severer laws concerning the trade and consumption of opium, while the Ministry of Finance owned and exploited about a thousand opium dens through its Opiumregie. He concluded therefore:

... this Department of the Opiumregie had to generate in these years of economic crisis a substantial part of the state income through the opium trade. Therefore, in the complaints about the dangers of misusing opium was hidden a good portion of hypocrisy. The state, in fact, aimed only at attacking its own competitors, which also happened in a juridically inappropriate way ... ${ }^{60}$ And about the situation around 1900: 'Very shortly after

59 He wrote the preface to E. Vanvugt (1995), p. 7-12.

60 Idem, p. 8. 
a new colonial war was won, the first building which was erected belonged to this Department of the Opiumregie or was an opium den. Even in areas like Lombok or Aceh ... the indigenous rulers stuck to their own severe punishment of opium consumption ... ${ }^{61}$

The first law or ordinance concerning opium was issued in 1872, and many followed. ${ }^{62}$ In May 1927 an attempt was made to collate all those separate ordinances into a single one, the Regie Opium Ordonnantie. After its first article with the necessary definitions came the following two articles:

Article 2. It is forbidden to grow poppy and Indian hemp. Article 3. The import, the possession and property, the stock and preservation, the transport, the preparation, manufacturing, processing, sale, use and export of narcotics, poppy and Indian hemp, including the import of coca leaves, are prohibited except as specified below. ${ }^{63}$

After learning what we have about the Opiumregie, opium and cocaine factories in those same years, we can only repeat the words of Baud, the 19th-century Governor-General, about the earlier VOC policy:

It is quite right that the Company prohibited the opium trade under severe punishments - even the death penalty - but it did not include itself in this prohibition. It never detested this trade, but detested the smugglers, who intended to profit from the same advantages. The Company increased the consumption of opium on Java twenty-fold, while complaining constantly that this was not enough. ${ }^{64}$

This remarkable continuation reproduces the immanent contradictions of every foreign colonial occupation.

The first modernization which took place was in 1927. Baud's remark is, in fact, explicitly mentioned in article 28: the prescriptions and decisions of this law 'do not concern the import ... manufacturing ... distribution ... [etc.] ... of the Government'. In addition, we have shown that the opium consumption not only did not decline up to the Great Depression, but that it was facilitated with new products like cocaine and that the government's profits increased tremendously. True, it is now difficult to prove that the consumption of opium on Java increased twenty-fold as Baud mentioned, but its price certainly did!

\footnotetext{
61 Idem, p. 11, 12.

62 Opium- en Zoutregie, p. 6-9, mentioned all 44 of them until the ordinance of 1927, a separate one for every part of the archipelago.

63 Idem, p. 12.

64 Idem, p. 116.
} 
The second modernization concerned the punishments. No longer the death penalty for the slightest infringement but, on the contrary, small fines for serious offences: 100 guilders for the druggist who sticks his narcotics in an unlocked drawer; somebody who plants large fields with poppy or Indian hemp (hashish) can get a maximum fine of 1000 guilders; a 1000 guilder fine can be imposed on a captain if his ship transports narcotics without the necessary papers and licenses (no quantities are mentioned); if this captain declares that he knew nothing about all those strange chests in his hold, he certainly pays less; if he is stupid enough to admit that he deliberately transported all these chests, he can get the maximum fine of 10,000 guilders, but he earns at least twenty times that amount from the cargo. ${ }^{65}$

Another modification was that the Opiumregie was established as a monopoly for the sale and manufacturing of tjandoe. As stated earlier, this must have been the result of a serious internal clash in the colonial bureaucracy. Even the first law of May 1927 provided the Opiumregie and its factory with an important position, but not the leading role. Given the overwhelming attention to medicinal matters, the responsible party must have been the Ministry of Health. ${ }^{66}$ This changed already in July 1927 , while its power was extended by January 1934 into an Opium-en Zoutregie (Opium-and Saltregie) and the leading party was the Ministry of Finance, which did not care about the health of the people, but only about its balance sheet.

The self-conceited perception of Opiumregie preceded this legal fixation: a multicolored map of the whole archipelago, always enclosed in its Annual Accounts from at least 1916 onwards (the first I could consult), is proudly announced as a 'General Map ... of the Area of the Opiumregie' while its 'Explanation' starts with 'The Property, etc. of the Opiumregie are ...' (see map 10 p. $3^{26}$ ).

65 Idem, p. $28 \mathrm{ff}$ the long article 25.

66 The Opium- en Zoutregie publication reproduces a chaotic situation from the point of view of law making. First, in this official publication of 1937, texts of - say-1927 are published time and again in the corrections of a later date. In this way it is difficult to reconstruct the bureaucratic struggles underlying these corrections. The first long ordinance (called the 'Narcotics Ordinance') is dated 12 May 1927 (p. 5-34). At the same day the equally long 'Regie-Opium Ordinance' was issued about the same subject (p. 45-55). In between a very short one (p. 35, 36) was published apparently only to fix the decisionmaking power among the various departments: for the import of raw opium, the head of the Opiumregie was responsible; for all opium business (from import to export) concerning medicinal aims, two other top bureaucrats (army and Ministry of Health); for coca leaves, the Ministry of Agriculture, etc. They all have the power to issue specific licenses. 
Notwithstanding this attitude of a monopoly, the Opiumregie's jurisdiction had its limits or, better, the consumption of its products (tjandoe, djitjing, tikee, raw opium) was limited. If you cannot pay with cash, you cannot buy the stuff. It was Queen Wilhelmina herself who "rightly" gave this order by Royal Decision (Koninklijk Besluit), apparently because a substantial percentage of it still arrived in her pocket through her shareholding of the Royal Dutch Trading Company (NHM). Furthermore, the Queen insisted that you had to be at least 21 years of age before starting to smoke opium. ${ }^{67}$

Other limitations of the Opiumregie were more serious. They were derived from a 'Circle Theory' and, in particular, a Circle practice. ${ }^{68}$ The archipelago was subdivided in 'open circles', 'mixed circles', 'license circles' and 'closed circles'. Within these areas, including the adjacent territorial waters, different rules apply for who was allowed to use the regie-opium (not its derivatives or even cocaine). A few remarks will suffice here.

Throughout the whole archipelago, it was forbidden for all military and police to use regie-opium, but this concerned all Europeans, in fact. In the few 'closed circles', specific areas where local leaders had forbidden narcotics for some reason, nobody was allowed to use government opium (and had to rely - if necessary - on smuggled narcotics); in 'license circles' nobody could use it without a license, a rule mostly in favor of Chinese license-holders (about 75\%); in 'mixed circles' license-holders and specific non-license-holders were both allowed to use the stuff; in the few 'open circles' there were no limitations, which concerned cities like Batavia or Surabaja and specific regions like one in East Sumatra or the Riouw archipelago. In the latter cases it was, apparently, too difficult for the Opiumregie inspectors to control matters.

The theory involved must concern some rather complicated knowledge about the ethnic composition of the archipelago's population and many regions. In the two appendices of this ordinance, all these locations are mentioned and who is allowed (or not) to accept the blessings of the bureaucrats of the Opiumregie.

67 For this very short text of 29-11-1932 see Idem, p. 55, 56.

68 In a law of 3 February 1934, this is legally fixed. See Idem, p. 64-89. 


\section{A Double Dutch End}

At the beginning of the Second World War, it must have been clear for every undergraduate analyst that the position of Dutch colonialism was untenable: the world had turned upside down, and nationalism destroyed the colonial basis internally. This happened everywhere in Asian colonies. Clever people realised this from 1900 onwards as a storm developed into a devastating tempest. First result: 1914-1918. For the second phase the Dutch government (in and outside Indonesia) apparently followed the French example of ignoring this weather forecast. It intended to fight against the hurricane to secure its "own property" and not to follow the English example of hiding since 1920 under an umbrella like the British Commonwealth.

The last Dutch colonial war became another disaster, whether the "enemy" was destroyed or not. As before, the Dutch were fighting in a country in which they were foreign exploiters. Neither the Calvinists nor the Catholics nor the Social Democrats showed any relevant understanding of this situation or of the legitimacy of repressing foreign people. The bill they had to pay now was again a huge one.

First, they had to fight three wars in a short period: against the Germans 'at home', the Japanese 'abroad', and now it invaded a sovereign and independent Indonesia. This under loud and continuous complaint of having lost a beautiful tropical milking cow called Tempo Doeloe, while blaming it on the victims. Next, the Dutch inevitably lost all "their" property, industrial enterprises, plantations, trade relations for decades, their goodwill with the USA and Asia, and so on. However, there was one advantage: the Dutch also lost the basis of their opium and coca image as - without any doubt - the first and largest drugs dealer in world history. Until now, Dutch historiography has tended to display blaming the victims attitudes, while generally unable to describe their past behavior and experiences in Indonesia in a realistic and down-to-earth fashion. Even this farewell to an opium dealership was celebrated by means of a very loud silence.

After its Declaration of Independence (17th of August 1945), the new, inexperienced and poor Indonesian Republic had to consider distributing opium in its first years also. Together with salt, forest products and petrol/ oil, opium belonged to the products with which it could gain some profit and pay for the costs of the new beginning and, in particular, a new army. ${ }^{69}$

69 B. Bouman, p. 102, $108 \mathrm{ff}$. It is important to say that the author is an historian, but also a Dutch general, who was a Dutch military and no deserter during the invasion of 
This was necessary because the Dutch had announced their intention to invade Indonesia, and they came back, armed to the teeth, to teach 'the rebels' a good lesson. This invasion started on the 2oth of July 1947. The Indonesians experienced how fragile their liberty was. Two and a half years after the return of the Dutch, the invaders definitely lost (27th of December 1949).

The Japanese had handed over the opium factory to Indonesia in September 1945, whereupon an Indonesian copy of the Opium- en Zoutregie was established as the Djawatan Tjandoe dan Garan. The new head was an experienced man, Raden Mukarto Notowidigdo, who had earlier served both the Dutch and Japanese management of the factory. At that time there was a stock of 24 tons of raw opium and one ton of prepared opium. ${ }^{70}$ Prices were announced in the press and

... in the period 1st of October to 31 st of March 1946 the Djawatan Tjandoe contributed 8.1 million guilders to the revenues of the state ... this was about four times the revenues of the Dutch in 1938, notwithstanding the loss of the markets of Sumatra, Banka and Billiton. ${ }^{71}$

As shown in Appendix 5 this conclusion is far from correct: the Dutch had a net opium profit of about 9 million guilders in $19388^{72}$ In addition, the triumphalism of Bouman is quite symptomatic.

The most serious mistake, however, is that the General simply changed rupiahs into guilders, apparently to support the comparison made with the pre-war Dutch situation and to demonstrate how "good" Dutch people were compared to these rebels. Only a few pages earlier, the first budget was reproduced in rupiahs, including the addition: 'All figures are in Japanese occupation currency. ${ }^{73}$ This money is, in fact, worthless inter-

Indonesia. For this episode see my article in H. Derks (ed., 1989), p. $296 \mathrm{ff}$. See also a main source of Bouman, R. Cribb, who wrote a highly ambiguous - to say the least-analysis of the Indonesian use of opium directly after Independence Day.

70 R. Cribb, p. 703 writes about 22 tons of raw and 3 tons of refined opium, which makes a substantial difference in value also. I have to reproduce simply what is told by Cribb and Bouman, who derived their data largely of suspected Dutch police, military and secret service sources.

71 B. Bouman, p. 108.

${ }^{72}$ What makes the difference between before and after the war is demonstrated by the Dutch Central Office of Statistics (CBS): if the 1900 guilder $=100$, the 1940 guilder $=15^{2.9}$ and the $195^{\circ}$ guilder $=312.4$.

73 This last quotation comes from R. Cribb, p. 705, note 5 , in all probability Bouman's source. But this Cribb made similar mistakes in his attempt to morally condemn the Indonesians of trading in opium. Once he wrote about the earliest provision of opium from the Indonesian government to the armed forces; it concerns a 'consignment of ninety kilos of raw opium ... therefore ... some 158,900 tubes of refined opium were provided ...' (Idem, 
nationally. In addition, immediately after the war at least four currencies circulated: Japanese, Dutch, "guerrilla-money" and the new rupiah!

The story continues: when the Dutch appeared on the horizon again, the Indonesians planned to transport the opium factory and a factory for medicines into Middle Java.

Between the end of November and the beginning of December 1945 the largest part of the opium stock-22 tons of raw opium-... was transported to Djokja and Klaten by a group of medical students. ${ }^{74}$

After this, nobody knows where the opium went: some say that 80 drums with raw opium went to East Sumatra from whence they were transported to Singapore. Anyway: the general report states that until May 1947, 'nearly no opium was sold'.

In that month (eight weeks before the Dutch invasion), there was no money left in the Indonesian Ministry of Finance (the manager of the opium during the Dutch regime), and it was decided to sell raw opium gradually in portions of 80 kilos. Again a month later, a Chinese merchant in Singapore paid 282,000 Straits dollars for 1,500 tons of maize and opium, whereupon the cabinet decided to sell all opium abroad. This opened new inroads into the Singapore connection, but we cannot follow that further. ${ }^{75}$

Apart from all the quantitative mistakes, which only prove that they are not very familiar with the subject they describe, it is more important that Bouman and Cribb exploited a perspective on this opium history

p. 718). Appendix 5 clearly explains how in the opium factory from about 200,000 kilo of raw opium, about 110,00o kilo prepared in tubes can be derived (including the weight of the leaden tubes). Thus, the go kilos of Cribb can never provide 158,900 tubes refined opium, but at most 99,000 tubes.

74 R. Bouman, p. 109.

75 If one follows the chronology mentioned by the General and calculates the quantities of opium involved, then this story becomes quite ambiguous. Take, for instance, the use of 80 drums with raw opium: suppose it concerns the standard oil drums of 55 USgal $=$ 200 liter, then we are confronted here with 16 tons of raw opium. Earlier he writes about 1 ton prepared opium in 'two drums of 500 liter': each drum holds 500 liters? two drums hold 250 liters each? Eighty drums of 500 liter gives 40 tons of opium (raw? prepared?), which were not available. In terms of chronology, the problem is not clear either. From October 1945 to the 1st of April 1946, apparently 8.1 million guilders was earned, but on November 1945 the whole stock had already been transported to a safe place, and until May 1947 no opium was actually sold. Or on the price side: is it possible in a rather chaotic Indonesia to sell raw opium within half a year for 8.1 million guilders (whatever the definition)? Or: per thail $(=0.04 \mathrm{~kg}$ ) the price of opium is on average 25 to 30 guilders in $1938 ; 8.1$ million guilders would be equivalent to 270 ,000 to 324,000 thails or 11-13 tons of raw opium. This is far from the 22 tons which was left or the original stock of 24 tons. And so on. 
which must be perceived as distorted after so many decades: for them the Dutch rightly returned to invade a then sovereign country and, anyway, foreign territory; the Dutch also rightly chased after the Indonesian opium traders, etc. Both write extensively about the opium (and rubber) 'smuggling' activities of the Indonesians, but they have "forgotten" that the latter were simply trading in their own country, which only the Dutch considered smuggling. It is a point of view with far-reaching consequences dating from the VOC time. And if the authors had had a genuine aversion against opium, they would have complained first against the Dutch Opiumregie which the Indonesians, compelled by necessity, had to copy for a limited time.

General Bouman dedicates his study 'to my Indonesian friends, former antagonists'. He and Cribb still wrote as enemies, probably overwhelmed by the data mostly provided by Dutch police, Dutch military and bureaucrats, including their secret services. All this cannot lead to an unbiased historiography. ${ }^{76}$

76 And not only this. As recently as 2010 the Dutch government refused any form of ideal or financial compensation for the slaughtering of Indonesian villages (several "My Lai's" must be celebrated) during this last colonial war. 